\title{
研究課題別事後評価結果
}

1. 研究課題名「テレイグジスタンスを用いる相互コミュニケーションシステム」

2. 研究代表者名及び主たる研究参加者名

研究代表者

舘 暲（東京大学大学院情報理工学系研究科 教授）

主たる共同研究者

廣瀬 通孝 （東京大学先端科学技術研究センター 教授）

原島 博（東京大学大学院情報学環 教授)

3. 研究内容及び成果

空間と時間の壁を乗り越えることと等価な体験を与え、バーチャルな意味での「存在感」の相互 提示を行うことがテレコミュニケーション(遠隔通信)のめざす理念である。本研究ではテレイグジス タンス(遠隔存在感)技術を用いることで、利用者がお互いに物理的に遠く離れていても、あたかも 同一の空間を共有し、すぐそばにいるかのように顔を合わせて会話することができる相互テレイグ ジスタンスシステムの開発を目標とした。従来のテレビ電話や臨場感会議方式の欠点であった「相 手の姿が平面的」「お互いの視線が合わない」「自然な視点位置移動ができない」という問題を解 決するものである。本手法においては特殊な眼鏡等を付けることなく、三次元映像の「提示」と「撮 影」とを同一の装置により実時間で行うことが可能となるという点が技術的に画期的な特徴である。 これにより相手が現前しているかのような臨場感の高いコミュニケーションを実現できた。

また、前述のシステムの開発を行うと同時に、相互テレイグジスタンス実現のための存在感の提 示手法についてさまざまなシチュエーションに対応した実装について研究した。人間にとつて使い やすい機械を考える際の基本である「人間を知ること」を常に考慮しながら以下に示寸要素技術に 分類して研究を行った。

実施において5年の期間を前期・後期に分け、それぞれの成果をまとめたシンポジウムを開催し た。前期においては試作的位置づけのシステムを構築し、調査・予備実験システムの構築などを 行い、人間の生理・心理的なファクタならびに、技術的な問題点などについて調查・研究を行った。 後期は、前期で得られた研究開発の基礎的データや基礎的知見をもとに各システムのブラッシュ アップや改良版の構築を行った。また、コミュニケーションの本質を解明し、最終システムの構築の ためのリファレンスとなるテレイグジスタンスシステム等を構築し、人間の生理・心理的なファクタなら びに、技術的な問題点なじについてさらなる調查・研究を行い、最終目標とする「次世代のコミュニ ケーション技術を開発」のための基礎的システムを構築、更には実際に使用可能な実証システムを 構築し、実験・検証等を行った。

（1）「相互コミュニケーションシステムの研究・開発」(舘グループ、廣瀬グループ)

互いに離れた複数のユーザがバーチャルに3次元空間を共有し、あたかも一堂に会して面談 
しているかのようにコミュニケーションできるようなシステムである。実際の開発に当たり、本システ ムの利用形態として電話機とのアナロジーから、相互テレイグジスタンスシステムを利用される用 途に合わせて以下の3タイプを想定した。

(i)オフィス・公共機関用テレイグジスタンス電話 $($ 舘グループ)

高品位の臨場感で相互コミュニケーションを行うことを目的とする。利用される環境としては図 書館、病院、駅などの公共機関あるいは、オフィスを想定している。

(ii)家庭用テレイグジスタンス電話(舘グループ)

相互コミュニケーションを低コストで行うことを前提とし、簡単なミーティングや家庭などでの使 用を想定した。

(iii)携帯型テレイグジスタンス電話 (廣瀬グループ)

携帯端末を介して相互コミュニケーションを行う。携帯性を重要な指針とし、存在感の提示を 目標として加える。

（2）人間の視覚特性や生理・心理的な特徵を考慮した知的ヒューマンコミュニケーションの研究 (原島グループ)

テレイグジスタンス電話の実装のみではなく人間の視覚特性や生理・心理的な特徵を考慮し た知的ヒューマンコミュニケーションの研究も並行して行い、得られた知見・設計指針を実装にフ イードバック、また、同時に効果的に実装する手段の研究・開発を行った。

「テレイグジスタンスを用いる相互コミュニケーションシステム」を実現するため、さまざまなシチュエ ーションに応じたコミュニケーションデバイスを実装し、実装されたデバイス間でのシームレスなコミ ユニケーションを実現するシステムの構築を目指した。

「オフィス・公共機関用テレイグジスタンス電話」としてはTWISTER II 〜 Vの4段階の試作機を作成 した。TWISTERの三次元映像提示においては、研究代表者らによって提案された「回転型パララ クスバリア」と呼ばれる手法を採用している。この手法は以下の2要素を兼ね備えている点が大きな 特徵である。(1)ユーザの視野をほぼ覆いつくす水平方向360度の領域に映像を提示(2)特殊な装 置を顔面に装着しなくても、ユーザは裸眼で立体映像を観察できる。このどちらか一方の条件を満 たした立体ディスプレイは存在するが、両方を兼ね備えた立体ディスプレイは他に例を見ない。ユ ーザの表情を隠蔽しないTWISTER は、コミュニケーションにおいて重要な役割を果たすハンバー バルな情報のやり取りを可能にする点で、高度コミュニケーションシステムの構築に適していること を実証した。

「家庭用テレイグジスタンス電話」としてはi-ball、i-ball 2、SeeLINDERを試作した。i-ball 2 はインタ ラクティブな透明球ディスプレイi-ball (interactive/information ball)のコンセプトに基づいて新たに 開発したハードウェアであり、レンズ系を使用して利用者の視点からは装置中央に備えられた透明 球内に映像が浮かんで見えるものである。i-ball 2 のインタフェースが直感的であるという肯定的な 意見が多く得られ、その情報提示の手法は評価が高く、新しいメディアとしての可能性を示唆する ことができた。SeeLINDERは回転する円筒の外側に向けて立体映像を表示する装置であり、360。 
どの方向からも立体映像を観察することができる。

「携帯型テレイグジスタンス電話」については情報取得型及び情報提示型ウェアラブルコンピュー 夕の機器構成についての研究を行い、「視覚・聴覚・場所・環境・感情」といった様々な情報の取 得、提示に必要な構成とその効果を確かめることができた。

また、コミュニケーションの手法や高度なコミュニケーションに必要なデバイスへの要求を明らかに する「知的ヒューマンコミュニケーション技術の研究」において、利用者がより高度な臨場感を経験 するための画像提示法、画像構成法などをはじめとする人間重視のヒューマンインタフェースを提 案した。

4. 事後評価結果

4-1. 外部発表(論文、口頭発表等)、特許、研究を通じての新たな知見の取得等の研究成果の状況 次世代のコミュニケーション技術に向けたテレイグジスタンス技術を用いた相互コミュニケーショ ンシステムの研究である。テレイグジスタンス(遠隔存在感)といういわば空想科学小説の世界の物 語をしっかり見据えて、優れた発想により着実な実験を重ねて身近な装置として実現している。テ レイグジスタンスの一つの方式を提案し、一貫してその実用化を目指して完成度の高い試作を行 い、その有効性を示した。近未来の遠隔会議システムや人工現実感生成にきわめて大きいインパ クトを与えるであろう。

具体的にはTWISTER、i-ball、SeeLINDERなどの三次元情報提示／取得装置を試作し、これら を用いた相互コミュニケーションを一般の人達が体験できるまでに完成度を高めたことは高く評価 できる。また、国際的にも著名な会議であるSIGGRAPHでTWISTERを発表、展示して高い評価を 受けるなど、国際的な評価も高い。

一方でこの成果が広く社会に受け入れられるためには、実用性、経済性、利用者の安心感、満 足度などの面から課題も多く残っており、今後はこれらの課題を解決して真に有用な相互コミュニ ケーションシステムへと発展することを期待する。

論文発表は国内 12 件、海外 5 件、口頭発表は国内87件、海外36件と件数はそれほど多くないが、 質の高い論文が発表されている点は評価できる。特許出願は国内3件、海外3件である。基本特許 出願後にCREST研究がスタートしたこともあるが、特許出願にはもう少し積極的に取り組んでほし かった。

\section{$4-2$. 成果の戦略目標・科学技術への貢献}

近未来の遠隔会議システムや人工現実感生成にきわめて大きいインパクトを与えるであろう。遠 隔会議システムが普及し始めてからいま一歩浸透が遅いのは、本研究のような遠隔存在感(テレイ グジスタンス)にそしいためと考えられる。遠隔会議システムにおける現実的な参加方式を検討す る場合に、本研究を避けて議論することはできないだろう。テレイグジスタンス実現への確実な一歩 をきざんだ研究であり、科学技術、戦略的にも評価できる。 
4-3. その他の特記事項(受賞歴など)

国際会議における4件の受賞は研究のレベルが高く、国際的にも高く評価されていることを示し ている。

TWISTERは日本科学未来館での一般展示に向けて準備が進められている。この展示を足がか りにテレイグジスタンスの一歩先のものを構想することも可能であろう。 